\title{
6. The Prosthetic Traumas of the Internal Alien in Millennial J-Horror
}

\begin{abstract}
Chapter Six presents an analysis of the RINGU (Hideo Nakata, 1998-1999; Norio Tsuruta, 2000) and JU-ON (Takashi Shimizu, 2000-2002) franchises alongside considerations of other influential J-horror films to illustrate the traumatic extent of the child's conceptual rebellion in these films. The chapter employs Alison Landsberg's 'prosthetic memory' and Angela Ndalianis's 'horror sensorium' to elucidate the particularly visceral ways that these children inflict 'prosthetic trauma' upon their audiences. In so doing, the uncanny child in these millennial J-horror films functions as a powerful - even traumatic - agent of counter-memory, dismantling the imagined coherence of Japan's national narrative.
\end{abstract}

Keywords: Childhood, Ringu, Internal alien, Prosthetic trauma, Countermemory, Progress

In resonance with the American and Spanish films previously discussed, the J-horror uncanny child's symbolic entanglement with deep national traumas erupts in a challenge to 'the pervasive invocation of the Child as the emblem of futurity's unquestioned value' (Edelman, 2004, 3). In the films analysed in this chapter - the RING and JU-ON cycles - the uncanny children defy and deconstruct the particularly claustrophobic welding of childhood to national progress in Japanese culture. These films have been chosen as metonymic and influential examples of J-horror; however, many other films of the millennial transition feature similarly subversive constructions of childhood, such as DARK WATER (Nakata, 2002), the ONE Missed Call franchise (Takashi Miike, 2003), The Locker (Kei Horei, 2004), and REINCARNATION (Takashi Shimizu, 2005). In all of these films, the J-horror child's traumatic temporal dissonance reconfigures the constrictive teleological model of national time that dominated the Japanese cultural

Balanzategui, J., The Uncanny Child in Transnational Cinema: Ghosts of Futurity at the Turn of the Twenty-First Century, Amsterdam University Press, 2018.

DOI: $10.5117 / 9789462986510 / \mathrm{CHO} 6$ 
imaginary prior to the ruptures of the Lost Decade. Thus, their function is similar to the uncanny children of Spanish horror, who emerged at the turn of the millennium in tandem with social groups that aimed to reshape the collective memory. Yet, beyond sparking an allegorical moment that enforces a reconsideration of the relations between the historical past and the present, the child characters in J-horror raise something akin to what Foucault calls 'counter-memory', a form of collective memory that challenges the dominant historical discourse by enacting 'a transformation of history into a totally different form of time' $(1977,160)$. J-horror children unmask the ambivalence and tensions that have long lurked beneath Japanese narratives of post-Restoration and postwar progress, the very narratives that the child is tasked with cohering. Counter-memory represents a mode of resistance against linear conceptions of time by raising a disruptive pluralism that stands against a homogenous official discourse of progress and history. As José Medina explains, counter-memory is 'not a pluralism that tries to resolve conflicts and overcome struggles, but instead tries to provoke them and to re-energize them. [...] This is a pluralism that focuses on the gaps, discontinuities, tensions and clashes among perspectives and discursive practices' $(2011,24)$.

In the Japanese context, pluralism disruptive of homogenous, historical time has specific resonance with the nation's quite recent, premodern temporal plurality, in which children were tied to their $i e$ and immediate locale rather than national progress. Via their temporally dissonant traumas, J-horror children reinvigorate this suppressed plurality. They raise countermemories not only through their embodiment of long-suppressed traumas, but by invoking visceral traumatic experiences for those with whom they come into contact - both other characters and audiences alike. At the crux of the narrative of each of the films considered in this chapter - and of many other J-horror films - is the adult protagonist's quest to synthesize the child's trauma into some semblance of coherent, linear narrative: essentially, to uncover the narrative kernel of lucid memory that elucidates the circumstances of the child's death, and the reasons for her subsequent vengeful rage. But these figures resist having their painful counter-memories resituated into a unitary narrative that coherently reorganizes chronological time and domesticates them as helpless victims - a resistance to linear progression provoked by the temporal incongruence of their trauma.

For this reason, Alison Landsberg's conceptual framework of prosthetic memory is a useful means by which to examine the affects and cultural work of these characters. As I outlined in Chapter Three, Landsberg's prosthetic memory describes the effect of films which are able to form powerful 
personal memories about past events within audience members who did not experience them directly. As Landsberg points out, there is a stark difference between apprehending a historical narrative about the past and subjective memories of past events we ourselves have experienced. Prosthetic memory 'emerges at the interface between a person and a historical narrative about the past, at an experiential site such as a movie theatre' (Landsberg, 2004, 2 ), as the affective register of the movie-viewing experience encourages spectators 'to not simply apprehend a historical narrative but [to take] on a more personal, deeply felt memory of a past event through which he or she did not live. The resulting prosthetic memory has the ability to shape that person's subjectivity and politics' (Landsberg, 2004, 2). Via her embodiment of trauma and subsequent sensory attack upon viewers, the J-horror child forges intersubjective relationships with characters and viewers in alignment with Landsberg's concept of prosthetic memory.

In fact, the eerie transfer of memory from ghostly child to those she haunts, and the subsequent tangling of the dead child's traumatic memories with those of her victims, is a major theme of millennial J-horror, mirroring the extra-diegetic manner by which the eerie affects of this fictional child become prosthetic memories for the viewer. Yet, in these films, it is not specific historical narratives that are rendered, as all of them are ostensibly set in the present - albeit an unstable present that is continually displaced by the weight of the past. These films instead impel audiences to experience the traumas lurking beneath the national narrative, traumas which disrupt historical continuity in such a way as to disallow the simple revisiting of history from the (supposedly) safe vantage point of the present. As Bliss Cua Lim points out in her discussion of temporality in Asian supernatural cinema, 'haunting, or the spectre's act of returning from death, is a refusal to complete the sentence, a worrying of historical knowledge' (2009, 160). The J-horror child not only refuses to finish the sentence started by dominant historical narratives of Japan's miraculous postwar progress, he folds the sentence back onto itself, suggesting that it was misguided from the beginning. The J-horror child thus raises in concentrated form what Landsberg refers to as 'the indigestible material of history' $(2004,47)$, inciting not just prosthetic memories, but prosthetic traumas.

Landsberg explains that memory is 'a sensuous phenomenon experienced by the body, and it continues to derive much of its power through affect' $(2004,8)$, and it is through this corporeal connection that film has 'the power to "suture" viewers into pasts they have not lived' $(2004,14)$. This suturing power is pivotal to both the aesthetics and the narratives of the films under discussion in this chapter, as the ghostly children trap characters and viewers 
within the cyclical replay of their traumatic deaths - or, more precisely, within the feelings of pain, terror, and powerlessness that underwrote their experience of dying. While Landsberg emphasizes the primacy of memory in her own work, she points out that 'prosthetic memories, like an artificial limb, often mark a trauma' $(2004,20)$. As millennial J-horror expresses, memory and trauma are cyclically entwined, as trauma itself represents an inability to fully synthesize, and thus to move beyond, a painful memory: an assertion at the crux of Caruth's suggestion that trauma 'is an experience not fully assimilated as it occurs' $(1996,5)$, which thus occurs largely retrospectively. As Giorgia Dona elucidates, trauma represents the abject space in which 'the remembered, the forgotten and the unspeakable coexist. Trauma politics and aesthetics go hand in hand' $(1999,18)$. The uncanny children of J-horror impel a realization that the very act of remembering is confounded by trauma: the aesthetics of their trauma thus figure a political intervention. The trauma both evoked and experienced by the Japanese uncanny child unsettles processes of remembering, especially the ways in which coherently assembled memories anchor secure personal and national identities.

Consequently, these children do not merely haunt those in their wake; instead, they inject their own traumatic experiences into the corporeal and subjective experience of those around them. This affect characterizes much J-horror film: as Wee states, dread elevates to horror in the genre 'when the boundary between Self/human and Other/monster collapses [...] when the Self and Other are largely indistinguishable' $(2013,209)$. The polysemic erosion of boundaries is also at the core of the internal alien outlined in the previous chapter; this precedent to the contemporary uncanny child, a common trope of post-Restoration Japanese fantastic literature, simultaneously embodies deep-seated anxieties within the psyches of adult protagonists while also existing as a monstrous, unknowable being external to them. The internal alien thus personifies prosthetic trauma. The eerie child carried on the back of the protagonist in Sōseki's seminal tale 'Dream of the Third Night' - considered in Chapter Five - is paradoxically both the man's actual, physical progeny and the embodiment of his repressed guilt over a murder he committed a century ago, raising the spectre of the murdered man. Echoing this tale, a common visual theme in J-horror consists of a ghostly child clinging to the body of his victim: a monstrously inescapable prosthesis upon the adult's body to which only the audience is privy. In addition, the traumas of the ghost are transported across physical space and time via technological portals such as videotapes, computers, televisions, and mobile phones. Through these technologies, the ghost's trauma-stained spaces 
are ungrounded from both temporal and geographical ties and invade the realities of other characters even when they are not in the vicinity of the child's death. These devices thus become vehicles for prosthetic trauma, not just for other characters but for the viewer as well, as the ghost threatens to transverse the seemingly impermeable boundary between reality and fiction and enter the space inhabited by the viewer.

Such an all-encompassing breakdown in spatiotemporal boundaries marks quite a point of difference from the films previously discussed in this book. In the American and Spanish films, the child compels us periodically to experience moments of frisson with traumatic pasts that rattle neat formations of linear, homogenous time both personal and cultural. Yet, the J-horror child, to use Lim's explanation of ghostly time in Asian cinema, forces 'characters (and those spectators who identify with them) to experience time with the ghost' (emphasis in original, 2009, 161). The unbridled temporalities of millennial J-horror thus delve fully into the deep implications that are ultimately displaced in most ghost films: if the existence of the ghost exposes the fallacy of linear, historical chronology, then the notion that time can be neatly reorganized once the ghost's requests are fulfilled may, in fact, be an all-too-hopeful mirage. In J-horror films of the millennial turn, progressive chronology cannot be restored once the ghostly child has unveiled its falsity.

\section{Prosthetic Trauma and the Horror Sensorium}

I consider the prosthetic traumas of the J-horror child via Angela Ndalianis's concept of the horror sensorium, which helps to understand the 'kind of experiences the senses mediate and give meaning to in our encounter with contemporary horror cinema' $(2012,30)$. Ndalianis's sensorium elucidates the way in which cognition, emotion, and sensation are fused in the horror experience, a conception of the relations between film and audience that allows consideration of the deep entwining of the cognitive and the visceral involved in the J-horror child's mechanics. While Ndalianis associates this process with the horror genre as a whole, I suggest that the films of this chapter foreground and revolve around the manner by which they interface with audiences, accentuating our conscious acknowledgement of the space where 'the medium and the human body collide' (Ndalianis, $2012,3)$. This heightened awareness of our coalescence with the events and beings on-screen is a primary reason for the child-ghost's effectiveness in invading the audience's psyche and body, and the resultant lingering of these affects long after the film has finished - residues of prosthetic 
trauma that crystallize the formation of prosthetic memory. The concept of the sensorium effectively demonstrates the ways in which the J-horror child incites cognition and sensation in a way intended to 'make me feel less secure in the actual space I occupy both while I'm watching the film and in the aftermath [...] the memory of it still lingering and eerily invading my everyday reality' (Ndalianis, 2012, 163).

In her final chapter, Ndalianis uses the climactic scene from RINGU to elucidate the extent to which horror films can engage the sensorium: she states that it is 'one of the creepiest horror scenes I've experienced' (2012, 163) as she, like Ryuji on-screen:

squirmed at the possibility of [Sadako crawling through her own screen]. Sure I knew it couldn't really happen, but that didn't stop the feeling that it might. [...] One of the most powerful effects that horror has is to be able to affect the sensorium in such a way that it perceptually collapses the boundaries between reality and fiction. $(2012,163)$

Here, Ndalianis raises the spectre of prosthetic trauma, as the viewer is confronted with a powerfully disquieting sense that her own reality has been punctured by the horrors on-screen. While I do not suggest that film-induced prosthetic trauma such as this is equivalent to that suffered directly, I do claim that these films launch an attack on the audience's sensorium so as to simulate the effects of trauma. I employ Ndalianis's sensorium in order to analyse the particularly visceral ways that the J-horror child provokes simulated traumas for the spectator. Because this affectual engagement with viewers invites a seamless merging of sensation and cognition, I use the term 'ideo-aesthetic' in the course of my analysis to articulate how these films quite powerfully intertwine aesthetics with ideology to elicit particular affects. Drawing back to Dona's point about the interlacing of trauma aesthetics and politics, the ideological agendas of these films are delivered via their complex aesthetic expressions of cultural trauma.

Consideration of how these films induce prosthetic trauma via their interaction with the audience's sensorium also helps to elucidate J-horror's lasting power not just in Japan, but transnationally, in a way almost unprecedented among foreign-language horror cinema produced outside of Hollywood - particularly remarkable considering the small production and marketing budgets of the films that sparked this trend, RINGU and JU-ON. As Landsberg explains, through the technologies of mass culture, 'prosthetic memories are transportable and therefore challenge more traditional forms of memory that are premised on claims of authenticity, "heritage", and 
ownership' (2004, 2-3). The sensory attack of J-horror resonates beyond audiences local to Japan: during the millennial turn, global audiences were compelled to experience the traumas ignited in a Japanese context but that can also be strongly felt within other personal and sociocultural contexts as prosthetic trauma. In the words of Caruth, 'trauma itself may provide the very link between cultures: not as a simple understanding of the pasts of others but rather, within the traumas of contemporary history, as our ability to listen through the departures we have all taken from ourselves' $(1995,11)$.

\section{'Do kids die too?': The RING Cycle}

Spanning the turn of the millennium, the RING cycle undergoes a complex meditation on the collapse of progress through its depiction of a ghostly child who harnesses the trauma of her death to unbolt both history and the process of growing up from linear time. While each of the original RING films projects a different overarching narrative - the first details an investigation into Sadako's videotape curse; the second centres on the scientific attempt to understand and contain the curse via a range of technologies; the third is a prequel detailing the circumstances of Sadako's death -, all three revolve around the affective kernel that is Sadako's trauma and the trauma that is Sadako.

The mythemic nucleus central to all three films, always knotted around the overarching plot as a painful yet vaporous past (and, in the prequel, as both the past and an impending future) is as follows: ${ }^{2}$ Sadako was a young girl with powerful psychic powers inherited from her mother, Shizuko. Tension is upheld throughout the cycle as to whether Sadako's father is Dr. Ikuma - Shizuko's lover who sought to prove to the general public that her powers were legitimate - or if she is the progeny of Shizuko's unholy union with a mysterious oceanic sea spirit. At a demonstration of Shizuko's psychic powers presented by Dr. Ikuma, a journalist interrupted the demonstration to declare vehemently that Shizuko is a fraud. Sadako employed her own

1 Quote from Ringu: upon his cousin's death at the hands of Sadako, Reiko's young son Yoichi plaintively questions the mortality of children.

2 The time structures of the films are complex, with multiple layers making up the diegetic past (Sadako's childhood past, the moment of her death, the time before Sadako's birth). For the purposes of this section, I take my cue from the films themselves and use the past tense in descriptions of Sadako's childhood and the events depicted in the cursed tape: moments that are always treated in the films as a particularly traumatic fork in time that hovers over the events in the overarching narratives. 
psychic powers to strike him dead. An indeterminate period of time after this event, Shizuko took her own life, and Ikuma, presumably threatened by Sadako's powers, hit her across the back of the head and tossed her into a well, closing the lid to prevent Sadako's escape and leaving her to die. From her watery sepulchre, Sadako projected her fractured memories onto a VHS videotape, suturing her trauma into the present in the form of a supernatural curse: anyone who watches this videotape is doomed to die within a week unless they copy the tape and show it to another, to ensure, in the words of one of the young children who brightly explains this process at the beginning of RINGU, 'It never ends. It just goes on and on.' Sadako thus unleashes prosthetic trauma on a mass scale, and via a process of unstoppable contagion.

Existing analyses of RING tend to be characterized by an imprecision as to whether Sadako is a child, adolescent, or adult, ambiguity that is understandable for it is reflected in strange but telling ways throughout the Ring cycle. ${ }^{3}$ Even Lury, who presents an insightful analysis of how RINGU's temporal subversions express anxieties about childhood in Japan, concludes of Sadako and other J-horror child-ghosts that 'the terrible deeds they commit and the secrets they know mean that we can no longer consider these ghastly figures children' $(2010,40)$. As is refracted in indirect ways in the scholarship on RING, Sadako's ambiguous oscillation between childhood, adolescence, and adulthood is central to the anxieties projected by the films and the way they interface with our sensorium, as will be explored in detail later in this chapter. It is particularly notable that the directors, Nakata and Tsuruta (RINGU o), and the screenwriter, Hiroshi Takahashi, chose not to depict the collapse in gender boundaries central to Koji Suzuki's book series, upon which the films are based. In Suzuki's first novel, Ring, Sadako is unambiguously depicted as a young adult, and the climactic twist occurs when she is revealed to be a hermaphrodite. Shifting the emphasis of the book to reflect the tensions underlying the millennial shift in Japanese attitudes towards childhood, the films' creators place the horrors of the films not along gender lines, as in Suzuki's books, but along temporal ones.

In fact, Sadako herself is barely present in the first two films of the cycle, despite looming over both as the monstrous aggressor - it is largely via her

3 A number of works on RING tend to resist classifying Sadako using age-suggestive terms, leaning instead upon the broad classification 'female' (see Richards, 2010; Wada-Marciano, 2009; and Wetmore, 2009), while some refer to Sadako as a 'child' or 'girl' (see Balmain, 2006; Lowenstein, 2009, 2015; Lury, 2010; McRoy, 2008; Tateishi, 2003; White, 2006), others refer to her as a 'teenager' or 'young woman', (See Wee, 2011a, 2011b, and Hand, 2006) and certain works largely position her as a 'woman' (see Haque, 2010 and Balmain, 2008). 
brief cursed videotape that her (non)presence is manifested in both RINGU and RINGU 2. She thus functions quite precisely as Caruth's traumatic 'wound that cries out' $(1996,4)$, which 'simultaneously demands and defies our witness' $(1996,5)$. Indeed, trauma's paradox of vision elucidates J-horror's overarching aesthetic of visual suspense, in which the power of the viewer's gaze is relentlessly undermined: Sadako crystallizes the manner by which the child-ghosts lurk on the edges and at the lower corners of the frame, making their presence known while refusing full capture within the visual field of both viewers and other characters.

\section{Sadako's Cursed Videotape and the Ideo-aesthetics of Trauma}

As I intimated in the opening of Chapter Five, it is significant that the VHS tape is the vessel for Sadako's curse, for this technology was intertwined with the sense of Japan's declining progress in the Lost Decade. As Lowenstein suggests, 'by having its curse recorded and played on videotape, RING [...] allegorically suggests that the electronic products that epitomized Japan's national strength in the 1980 s, such as televisions, VCRS and videocassettes, no longer "work" in the recessionary 1990s' $(2015,89)$. At the pinnacle of Japan's rapid economic progress from the late 1970s to the beginning of the 1990s, VHS videotape was one of Japan's key emblems of technological success, having been invented by the Victor Company of Japan. The company had attained celebrated postwar success, including developing subsidiaries in the U.S. and Europe in the late 1960s and 1970s (a reversal of its original status in the late 1920 as a subsidiary of an American company). As Phu points out, the VHS tape sealed in 'its victories with competing developments such as Betamax [another Japanese development], the laserdisc and electronic disc, Japan's much envied stature as a technological superpower' and became associated with the 'dominance of a "national" innovation' (2010, 53). VHS was the success story of a Japanese company that won the hard-fought battle for technological domination of the home entertainment sector at that time. Yet, while VHS was ubiquitous at the time of RINGU's domestic release in 1998 , the mechanics of Sadako's curse quickly seemed antiquated with the rapid replacement of VHS by DVD: as Caetlin Benson-Allott charts, DVD was launched in America in 1997 and, by 2001, DVD sales exceeded those of VHS $(2013,14)$. Thus, in 1998, Sadako infected an analogue device that symbolized Japanese technological supremacy at the very moment when it was tipped to be overcome by the technological paradigm shift to digital storage: an uncanny evocation of stalled progress that resonates with the anxieties of the Lost Decade. By entwining Sadako's curse with degraded 
VHS technology, RINGU raises a premature, but seemingly prescient, uncanny nostalgia for the fitful, grainy qualities of analogue video. In fact, even in 1998, Nakata consciously endeavoured to enhance the imperfection of the analogue image by passing it through a computer to enhance the washed-out, snowy quality (Nakata, 2000, n.p.).

All three Ring films revolve around the eerie images contained on Sadako's cursed videotape, which is threatening in its incoherence and lack of clarity. RINGU follows the attempts of protagonists Reiko and Ryuji to decode the tape in an effort to lift the fatal curse, a task that they learn, all too late, is impossible. Even after they analyse the tape's mysterious images to locate Sadako's corpse at the bottom of the well and provide her remains with an appropriate burial, Sadako still mechanistically enacts her curse, erupting from Ryuji's television screen and striking him dead with her monstrous gaze. Aesthetically paralleling Sadako's own fluctuation between child, teenager, and adult, the cursed tape enacts a plurality of different temporal modes that strain against one another. Such temporal plurality aligns with Lim's Deleuze-inflected concept of 'immiscible times': 'multiple times that never quite dissolve into the code of modern time consciousness, discrete temporalities incapable of attaining homogeneity with or full incorporation into a uniform chronological present' $(2009,12)$. In so doing, the horrors of Sadako's trauma, to use Deleuze's terms, 'plunge viewers into time rather than through space' (1997a, xii) in quite marked ways that resonate with the child-centred anxieties of the millennial turn in Japan.

The images on the tape occur in a disconnected string, which, in each RING film, withstands the protagonists' and viewers' attempts at contextualization; each strange image cuts to another before we have a chance to comprehend fully what we have witnessed, and, in total, the tape - while threateningly looming over all of the RING films - is just under a minute long. The surreal imagery on the tape includes: a man peering into a well (filmed from within the depths of the well), spatially indistinct traditional interiors, floating kanji characters (which seem to spell 'Eruption'), a mass of people writhing on all fours, a man with a towel on his head standing before the ocean, a reflection of a sedate woman in a kimono brushing her hair in an oval mirror (revealed in RINGU to be Sadako's mother Shizuko), a strangely shaped eye - both human and horse-like - with the Japanese character for 'Sada' (which means 'chaste child' or 'pure one') reflected upon its surface, and finally, a well in a forest clearing. The soundscape of the tape indiscernibly melds machinic and organic sounds, including a cacophonous, low rumbling - which suggests an incoherent babble of human voices as well as audio static - and a rhythmically intermittent, high-pitched 
scraping sound: a harsh sound that evokes the buzzing of insects as well as the mechanical screeching of magnetic tape speeding through a spool. In its disorienting resistance to ontological characterizations and narrative structure, Sadako's video pollutes the symbolic coherence of all the RING films, which set out to follow traditional ghost mystery arcs in which the precise details of Sadako's traumatic death are uncovered and her unquiet spectre is satiated. The tape thus renders both the intensity and enigmatic corrosion of traumatic memory, while constituting a challenge to the narrative process of domesticating memories of past traumas via linear and cathartic narrative resolutions.

In contrast to the smooth, muted colour palette of each film's overarching diegesis, the VHS imagery is characterized by a degraded, snowy aesthetic that incites the spectator's sensorium through a gradually intensifying cognitive engagement - specifically, a building awareness of delayed recognition, as will be detailed - facilitated by an eerie, haptic quality. As RINGU progresses, the tape's grainy aesthetic comes to constitute a threat, for it conceals Sadako's gradual appearance from within the well in which she died, which is depicted in the tape's final shot. Each time the tape is replayed as Reiko and Ryuji attempt to decode its imagery, Sadako hauls herself slightly further over the rim of the well before this final image erupts into static and the video ends. The floating grain thus obscures the spectre's gradual emergence from the well between progressive viewings of the tape. In some of the earlier instances in which the tape's final shot is shown, the viewer may notice some odd flicker of movement near the well's rim - actually the appearance of Sadako's hand - but associate it with the grain of the degraded image. It is only when Sadako crawls out of the well and erupts through the television screen in Ryuji's living room in the climactic scene that it becomes clear what the grain concealed.

The decaying quality of the image thus belatedly impels spectators to consider their relationship to the screen. As Laura Marks points out, aesthetics of image decay such as graininess 'discourage the viewer from distinguishing objects and encourage a relationship to the screen as a whole' $(2000,172)$. This affect becomes particularly potent when Sadako is pictured climbing through the diegetic television which projects her image at the film's climax, as our felt proximity to the screen is belatedly registered as a threat. The images on the tape are haptic in that that visual grain compels our eyes to graze their surfaces, troubling the simple engagement engendered by crisp, clean images and encouraging 'a more embodied and multisensory relationship to the image' (Marks, 2000, 172). This embodied mode of engagement in RINGU provokes a reflection on the way our own 
memories interface with and give meaning to the tape's images: as Sadako finally pulls herself out of the well and then escapes the bounds of the television screen at the end of the film, the audience is impelled to sift through their memories of the previous depictions of the cursed tape's final shot in an attempt to pinpoint when they may have first experienced a flicker of cognizance that the spectre was emerging. The grainy imagery thus aestheticizes the paradoxical power and intangibility of traumatic memory, in which much of the discomfort arises from being unable to remember coherently, and also the frisson involved in realizing too late the extent of the threat with which one has been confronted - a potent evocation of trauma's belatedness. Audiovisual television static heralds Sadako's imminent appearance throughout RINGU, to the point that spectators are primed to dread the sudden, piercing hiss of television snow, even before they are aware of the nature of the threat that it issues. The eruption of this audiovisual static into the coherently assembled shots that constitute the film's narrative is a compelling aesthetic metonym for the disruptive incoherence of Sadako's trauma.

\section{The Traumatic Curse of Counter-memory}

Through her cursed tape, Sadako activates a particularly uncanny form of counter-memory for Japan's past that disrupts historical narratives structured around growth and progress. The tape reshapes comforting nostalgia for traditional Japan and furusato (meaning 'hometown' or 'native place' and connoting traditional rural farm villages) ${ }^{4}$ and suffuses it with dread. The images on the tape are shot using muted frontal lighting, which makes the spaces and images appear almost impossibly flat, recalling the frontal lighting and resultant flattened aesthetics of Kabuki theatre and very early Japanese film, which was mimetic of Kabuki. ${ }^{5}$ This vague aesthetic of

4 Nostalgia for furusato is in fact a major trend in Japan, even though a vast percentage of Japanese have lived all their lives in cities and do not have a rural hometown to which to return. Nostalgia for an imaginary furusato represents an attempt to forge some sort of connection with an 'authentic' traditional Japan: as Jennifer Robertson states, furusato is 'a cogent and compelling signifier for, and symbol of, things Japanese' $(1988,495)$ and the continued craving for it in the present is motivated by 'a nostalgia for nostalgia, a state of being provoked by a dissatisfaction with the present on the grounds of a remembered, or imagined, past plenitude' $(1988,495)$.

5 In The Aesthetics of Shadow, Daisuke Miyao (2013) details the development of Japanese lighting techniques, and points out that early film techniques were much indebted to the flat aesthetic of Kabuki theatre. In fact, as Miayo explains, there was much resistance in the early decades of the Japanese film industry to three-point Hollywood lighting techniques, so integral was this flat aesthetic to ideas of Japanese cultural authenticity. 
pastness is further reinforced by Reiko and Ryuji's realization in RINGU that there is an outmoded regional dialect submerged in the staticky, hissing soundscape of the tape, which leads them to Oshima island off the coast of Tokyo, where Sadako grew up. Oshima is depicted as an isolated fishing village in a state of economic decline due to a history of volcanic eruptions (vaguely suggested on Sadako's tape by the word 'Eruption') and an ageing population - an atavistic community left behind by the rapid progression of urban Japan. While on Oshima, Reiko and Ryuji stay in Sadako's childhood home, inserting themselves into the spatial manifestation of cultural pastness represented by the traditional house that appears in flat, fragmented form on Sadako's tape. In the present, it is an unbearably quiet and still space inhabited only by Sadako's aged, distant relatives. Reiko and Ryuji discover that Sadako was murdered in Izu, an island province near Tokyo, which, like Oshima, is part of the Izu peninsula. Izu is currently a popular tourist destination, but, as depicted on the tape, was a rural area at the time of Sadako's death. The well in which Sadako's corpse has festered for 30 years has since been built over by a holiday resort - Reiko and Ryuji have to crawl underneath a cabin to locate the well - further emphasizing Sadako's entwinement with past modes of Japanese existence rapidly built over in the quest for rapid economic progress. Thus, as mediated through the decaying aesthetics of a soon-to-be outmoded technology, the video eerily depicts a mode of existence that is quickly becoming past in progress's wake.

Further resisting linear historical constructs, the recent pasts conjured by Sadako's degraded tape collapse into the more distant pasts suggested by the video's Kabuki-esque aesthetics. Similarly, the tattered gown that Sadako wears points to multiple temporal sheets. Throughout the first two films, her brief appearances evoke the onryō of traditional Noh, Kabuki, and ukiyo-e through her long white burial gown and the dark, lank hair that covers her face: the typical hallmarks of the onryo who traditionally returns from death to seek vengeance or because proper burial rights were not completed. ${ }^{6}$ Yet in RINGU o, it is revealed that Sadako wears this white gown because she was performing in a play, aptly named 'The Mask', on the day that she died in the late 196os. The play seems to draw on modern Western traditions, in particular the musical The Phantom of the Opera (Andrew Lloyd Weber, 1986) and French horror film Eyes Without a FACE (Georges Franju, 1960), more than ancient Japanese ones.

Yet, when she is paired with the image of the decaying well in her tattered gown, Sadako's recent (and strongly Western-influenced) past reverberates 
with much more distant ones: the well is a particularly potent signifier of premodern Japan, recalling folktales such as 'Banchō Sarayashiki' (a direct influence on RINGU's narrative, as outlined in Chapter Five), as well as the famous autobiographical story 'The Fox' by early modern author Nagai Kafū, first published in 19og. Like the RING films, 'The Fox' filters a meditation on haunted nostalgia through the lens of troubled memories from childhood: the story details Kafü's childhood fears of a well at the centre of an abandoned traditional garden below his father's modern house. In 'The Fox', this well seems to be the eerie, foreboding vessel for the premodernity that the country is in the process of displacing in the name of progress. The well through which Sadako emerges similarly functions as a spectral rem(a)inder of deep layers of suppressed pasts throughout the RING cycle. That Sadako is depicted erupting through two thresholds simultaneously in RINGU's most famous sequence - that of the well and that of the television screen - thus suggests dual layers of temporal transgression, as a girl who died 30 years ago thrusts her presence and experience into the present, while also stirring the cyclical, numinous temporalities of premodernity.

Because they raise such a layered evocation of temporality, the images on Sadako's tape function in a way that aligns with what Marks (2000, 24-33) has termed 'archaeological' images. Marks draws from the Deleuzian concept of the optical image to pinpoint how intercultural films engage with multiple layers of cultural memory in deconstructive acts of historical excavation (25). In such cinema, archaeological images evoke multiple layers of the past, instead of a singular past with a secure place on an established historical continuum, refiguring time not as a homogenous line but as multilayered depth. As Marks suggests, archaeological images encourage us to relate to them via complex processes of memory, rather than by moving forward in time through a sequential linear narrative. As she states, such images reveal 'new history as it is being formed, the new combination of words and things that cannot be read in terms of the existing languages of sound and image but calls for new, as yet unformulated languages' (Marks, 2000, 31): a description that suggests the disruptive, plural power of counter-memory. Sadako's video seems to reconstruct history by harnessing and layering the signifiers of Japan's cultural past in its construction of childhood memories fractured by trauma. The uncanny temporal contortions of Sadako's video are thus manifested through its aesthetic properties in a way that disassembles the linear chronology of Japan's modern time consciousness.

This ideo-aesthetic rebellion is also encapsulated in the fractured, tortured movements of Sadako as she approaches her victims. Slow and rhythmic - especially in their accord with the staccato non-diegetic score 
- Sadako's movements suggest the measured discipline of traditional Noh dance, a style performed since the fourteenth century, which requires highly trained dancers and has become synonymous with a romanticized projection of culturally authentic Japan, as the oldest form of major theatre art still regularly performed (Faubion Bowers, 1974). Yet, Sadako's movements are also painfully spasmodic, rigid, and jerky, eerily defying the smooth continuity of both typical bodily movement and the fluid motions of Noh dance: an effect Nakata achieved by having the actress - seasoned Kabuki performer Rie Ino'o - walk backwards in fitful motions before playing the film in reverse (Fig. 14). These strange movements refract the style of Butoh, a form of performance art which seeks to rebel against highly codified, aristocratic modes of traditional Japanese performance such as Noh.

Butoh arose in the turbulent postwar period, introduced in 1959 by Tatsumi Hijikata and Kazuo Ohno, and sought to, in the words of Bonnie Stein, explore 'the dark truths that hid behind the Japanese social mask' (2001, 378). Essentially, the term can be interpreted as 'dance of darkness' or 'dance of the dark soul' (Vicky Sanders, 1988, 149). Butoh aimed to coopt and pervert the basic styles of traditional Noh and Kabuki - to resurrect and challenge them simultaneously - in an effort to resist the Western modes of dance and performance infiltrating Japanese culture postwar. In so doing, Butoh sought both to question Westernized modes of national progress and express the suppressed traumas of Japan's fractured postwar consciousness. Often, Butoh dancers such as Ohno would adorn the garb typical of Kabuki and Noh performers, such as kimonos (often the female version, in a defiance of gender boundaries), as well as heavy white face makeup reflective of both Kabuki and the wooden masks typically worn in Noh, an implication suggested by the performer's fixed facial expressions. As Sanders suggests, 'Butoh dancers use a fresh, sometimes nightmarish vocabulary of grimace and gesture that seems at once prehistoric and futuristic' $(1988,150)$. Butoh's movements can be characterized as an uncomfortable and deeply unsettling array of painful bodily contortions, which, in its multilayered avant-garde style, is a literal embodiment of trauma that rails against Japan's postwar progressive time consciousness (Fig. 14). Thus Butoh, like Sadako's degrading videotape, deploys the aesthetics of trauma to launch an ideo-aesthetic challenge to postwar fixations with progress and futurity.

In its powerful evocation of counter-memory, Sadako's tape collapses together the different modes of address that typically separate national history from personal memory. The viewer and other characters become enfolded in and are forced to sift through a past childhood trauma as if it were a broader cultural history, rather than the fractured memories of a 

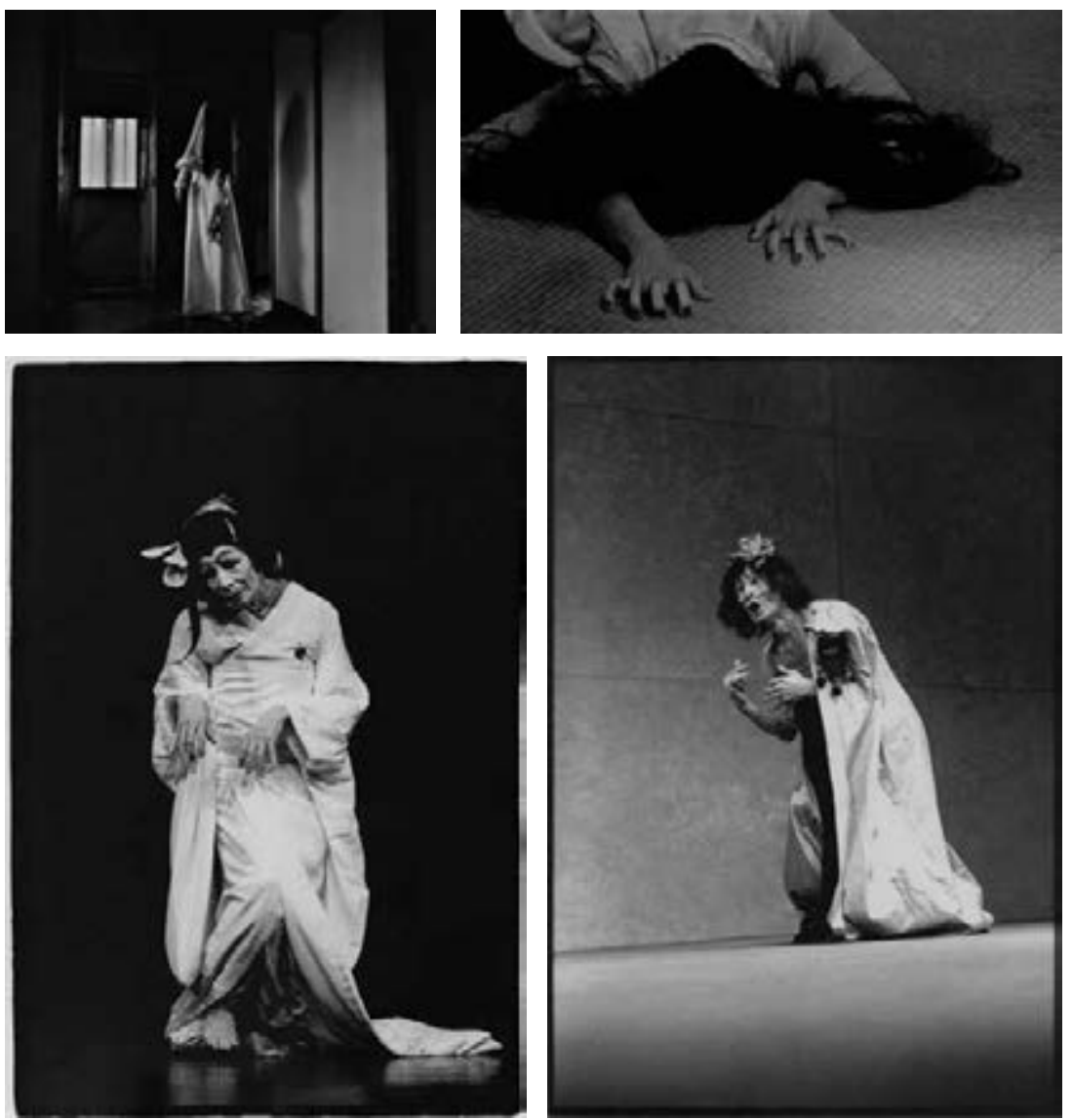

Figure 14. Top from left: RINGU 0 and crawling through the television in RINGU. Bottom: Kazuo Ohno performing Water Lilies (1987); photographs by Nourit Masson-Sekine (1988).

forgotten dead girl - an explicit evocation of prosthetic trauma. In defining counter-memory, Foucault proposes just such a replacement of 'objective' historical narratives with personal memories and genealogies (1977, 139-164). As a result of its prosthetic trauma, Sadako's tape powerfully conjures the 'insurrection of subjugated knowledges' $(2003,10)$ that Foucault asserts is the project of counter-memory. As Medina explains:

when it comes to knowledge of the past and the power associated with it, this battle involves resisting the 'omissions' and distortions of official histories, returning to lost voices and forgotten experiences, relating to the past from the perspective of the present in an alternative (out-of-themainstream) way. $(2011,13)$ 
Rebelling against the child's conventional function to embody national continuity and thus sustain ever-advancing national progress, Sadako instead harnesses her past trauma - inflicted by the very adults responsible for her care - to dismantle the imagined coherence and homogeneity of Japan's modern time consciousness. This ideo-aesthetic 'insurrection of subjugated knowledges' $(2003,10)$ rebels against homogenous narratives of Japanese history, while potently expressing the belated recognition in the late 1990 s that, while children as both ideological apparatus and as subjects have sustained celebrated mythologies of rapid postwar progress, they are also the long-unacknowledged victims of this pervasive entanglment of personal growth and national advance.

\section{Sadako's Fluctuation between Child and Adult}

In concert with the archaeological images on her tape, as I previously suggested, Sadako's 'growth' does not adhere to the strictures of linearity. For most of RINGU, Sadako's ghostly image takes the form of a small child: she appears as such in the video that bears her curse, and also in the intersubjective flashback to the moment she killed the journalist (a vision that briefly fills the whole screen as Sadako imposes her memory upon Reiko and Ryuji). Yet, towards the end of the film, when Reiko and Ryuji finally discover the well in which Sadako died and experience another intersubjective flash of Sadako's past - the moment that Ikuma attacked her and threw her down the well - Sadako appears eerily tall and stretched. Similarly, the monstrous creature who crawls through the television screen to murder Ryuji in the climactic scene is rendered abject through the unnatural contortions of her elongated, lean body, a corporeality that conflicts with that of the small girl depicted earlier in the film. Further obfuscating the unstable timeline of her existence, in RINGU 2, it is revealed that Sadako in fact remained alive in the well for 30 years, dying only a year or two before Reiko discovered her corpse - a disconcerting muddying of narrative time, as Sadako's body was depicted in an advanced state of decay in RINGU.

The prequel further unsettles the temporal continuum to which Sadako is bound. As intimated above RINGU o: BIRTHDAY (a title which points to the cycle's preoccupation with Sadako's development) is set 30 years before RINGU and RINGU 2 in the late 196os - a cultural moment in which both postwar progress, and Butoh dance, flourished - and depicts Sadako as a socially and mentally stunted nineteen-year-old girl who unknowingly places a deadly curse upon almost everyone she encounters. Yet, it is revealed that this seemingly innocent teenage Sadako is latently inhabited, and, at 
moments of fear or rage (kireru), taken over by, a second version of herself: the child incarnation of Sadako. This child Sadako, who constantly evades full capture in the visual field even of this film, seems to exist within the depths of the teenage Sadako's own psyche as a residue of Sadako's traumatic memories, while simultaneously possessing corporeal form in the film's present.

It is suggested that after Sadako murdered the journalist at Shizuko's demonstration of her psychic abilities - which, as in RINGU and RINGU 2, remains a powerful but elusive moment in the film's diegetic past -, Sadako split into two versions of the same self. Ikuma captured the version of Sadako that he believed harboured murderous inclinations, and locked her in the attic, injecting her with chemicals to ensure she did not develop on her own terms - a forceful allegory for the previous generation's culpability for the stultifying conditions surrounding childhood in Japan at the turn of the 21st century. It is only when this monstrous child reasserts herself inside the psyche of the soft and gentle teenage Sadako that she loses control of her psychic powers and kills or torments those around her. At the film's climax, frightened members of Sadako's theatre troupe track her down and brutally beat her, facilitating the child's complete takeover of Sadako's bent and broken body to wreak vengeance upon all of her aggressors, leaving none alive in her wake. It is after this massacre that Ikuma tosses his daughter(s) into the well. The child Sadako is thus a particularly threatening incarnation of the internal alien, existing outside of Sadako's being as a corporeal entity in the present while simultaneously lurking deep within her psyche as a partially obscured traumatic past. Echoing Sōseki's tale, at the conclusion of RINGU o, the internal alien restates her primacy within the psyche of the teenage Sadako, folding the process of growing up back onto itself at the very moment of her transition into adulthood.

The affects of this temporal looping are extended to the viewer throughout the film cycle: in a simulation of being engulfed by a long-latent childhood trauma, Sadako and her fractured memories function like an internal alien for the viewer as well. The films revolve around the implication that Sadako's traumatic images have the power to extra-diegetically infect the viewer's mind, for we have also been exposed to her videotape curse in the process of watching the film(s), a conceit invoked with further potency by the climactic realization in RINGU that Sadako has the ability to erupt through the screen which projects her image and enter the real space of the spectator. Sadako's temporal multiplicity underpins the prosthetic traumas of this internal alien, as it remains impossible to locate her at one particular developmental stage along the continuum from child to adult throughout the cycle. Between 
appearances, her corporeality seems to stretch and contract, unsettling the audience's temporal grasp by impelling them to question whether their previous perceptions of Sadako were accurate. Reflecting trauma's paradox of vision, in relating to the character of Sadako, we are unable to construct a coherent linear narrative of growth and development from the snippets of her past that we are offered, in a way that challenges the authority of our own gaze and powers of comprehension: we instead engage in an uncertain process of reflection and comparison between the image before us and earlier memories of what we may or may not have seen.

\section{Attentive Recognition and the Ideo-Aesthetics of the Internal Alien}

This stymied mode of recollection is in large part enacted by Sadako's evasion of full capture within the camera and viewer's gaze. In fact, the first time we see her in RINGU, it is via a darkened mirror reflection on the cursed videotape: as we watch the mirrored reflection of Shizuko brushing her hair, the mirror shifts for one moment from the left side of the wall to the right, and for this instant Sadako's image is briefly reflected, receding even as it appears. During Reiko and Ryuji's analysis of the tape, this shot is put under particular scrutiny, as Reiko pauses the tape in an attempt to capture that image and questions 'What is that?' In trying to 'capture' Sadako as a character by piecing together these brief, barely tangible images, the viewer undergoes a process of attentive recognition, a mode of perception outlined by Deleuze ${ }^{7}$ in relation to what he calls the 'optical image' - the inspiration for Marks's aforementioned archaeological image. During attentive recognition, the perceiver is forced to oscillate between the fragmented, incoherent image that the film presents, and the images that it brings to mind - whether these are memories drawn from earlier in the film, or from the perceiver's own prior experience, or her imagination, or an indiscernible combination of the three. After undergoing this psychic process, the viewer returns to the image so that the memories drawn forth can assist her attempt at comprehension. As Deleuze explains, images that incite attentive recognition are 'necessarily poorer and more rarefied' (1997a, 44) as we are shown 'pure descriptions which are unmade at the same time they are outlined' (1997a, 45) - a fitting description for the grainy, black-and-white image of Sadako receding into the shadowy depths reflected by the mirror.

Because Sadako's memories are emitted via her cursed video, the films amplify the rather uncanny affects of attentive recognition by diegetically 
foregrounding the entanglement of memories raised by optical media with an individual's own subjective processes of memory. For instance, in RINGU 2, a scene early in the film depicts a forensic scientist's attempt to reconstruct Sadako's face from the information garnered from her remains. The result is a plasticine model that is curiously devoid of distinguishing facial features, extending the first film's tension surrounding Sadako's unknowability. One of the investigators starts to take photographs of the model, and, with each flash of the camera, an uncanny face briefly overlays the blank plasticine replica, the texture and hue of a photographic negative. Yet the 'face' disappears with the light of the camera flash, and we are forced to question what it is we really saw and provide the image with substance by patching together our own vague memories or internal visualizations of Sadako's appearance. The vague and elusive 'memory' of Sadako's face is thus drawn forth by the flash of the camera, as optical media technology becomes a prosthetic vehicle for memory, working in a circuit with the subjective memories of other characters and the viewer.

The affective relationship between film and viewer ripples out to the deep ideological tensions the films express. As Ndalianis explains, 'our cognitive engagement with the ideological issues raised by horror films $[\ldots]$ rely on our sensory responses to horror' $(2012,20)$. The sensory effects of the films' aesthetics express an all-encompassing unsettling of Japanese progress that is played out via an anxiously belated rethinking of both growth and childhood. In a succinct example of such ideo-aesthetics, in the first film, a black-and-white, photographic negative effect occasionally intrudes upon the muted, realist colour palette of the main narrative, an effect which resembles the flash of Sadako's face described above. When Sadako's victims - almost always teenagers on the brink of adulthood - die, their terror-contorted faces are depicted using this chromatic shift, and throughout the cycle these images often abruptly erupt into the diegeses in concert with a piercing electronic scraping sound (the distorted sound of a camera flash, which also evokes a human scream and the high-pitched squeal of Sadako's tape). The jarring effect interrupts our smooth interaction with the linear narrative as we experience a sensory jolt. At the same time, this effect potently condenses the way this internal alien derails progressive temporal vectors, demonstrating that Sadako's curse shuts down the subjectivity of her victims, immobilizing their future potential as they become frozen as degraded mediated images in her archaeology of the past.

This same ideo-aesthetic effect contributes to the feelings of dread conjured by RINGU's final shot, a wide shot depicting Reiko driving toward a grey horizon with her son, Yoichi, in the car. Yoichi has watched Sadako's 
cursed tape, and is doomed to die unless Reiko shows someone else the tape, and she has chosen to show it to her father. As she drives towards the horizon, the voice of the child that she interviewed, yet calmly dismissed, at the beginning of the film is replayed, stating 'It never ends, it just goes on and on.' Just before the screen fades to black, the image of Reiko driving becomes a static, black-and-white image. This shift is almost imperceptible at first due to the dark sky, yet the film lingers for a moment on this static image before the screen blackens. RINGU thus leaves us on an unsettling evocation of stalled progress, mediated through the voice of a child we heard in the early moments of the film who understood all along that Sadako's curse is not conducive to linear resolutions. Thus, the film ends with the frisson of an eerily delayed recognition of the power of past childhood traumas to reconfigure narrative time from behind, a recognition that in turn unsettles the child's binding to growth, progress, and futurity.

Ultimately, throughout the RING cycle, few external temporal coordinates are offered to the viewer to help construct a linear pattern of growth for Sadako Yamamura: the instances from Sadako's past simply erupt into the film's diegetic present as grainy, sepia coruscations, overcoming the muted colour palette of the film's diegetic real - flashes of the past which briefly dominate the whole screen like a traumatic memory. As viewers, we become enfolded in the few eerie images that circulate around Sadako's childhood trauma, and are encouraged to engage with them via our own processes of attentive recognition. Marks suggests that this deeply personal process of engagement can be disturbing and even traumatic $(2000,48)$, as is the intention in RING: the boundaries between film and screen seem to waver as our memories interface with the floating memories of Sadako on-screen. This affect is enhanced by the aesthetics of technological decay and degradation that characterize Sadako's imaging of pastness, as her traumatic images intrude upon the films' narratives as though they have emerged from a layered, indiscernible combination of psychic and historical pasts beyond the diegetic realm of each film. The cyclical, repetitive way Sadako's images reverberate throughout all three films evokes the relentless repetition of her traumatic past: the films cycle around a traumatic event and impose the fragmented memories of it upon our consciousness without directly or coherently depicting it. These aesthetics thus simulate the affects of trauma, inciting 'a larger relation to the event that extends beyond what can simply be seen or what can be known [...] inextricably tied up with the belatedness and incomprehensibility that remain at the heart of this repetitive seeing' (Caruth, 1996, 92). Sadako's childhood trauma becomes our trauma: we too have now become cursed by the images on her tape - a recognition 
that occurs long after we are first exposed to it in the course of watching RINGU - as the prosthetic technologies Sadako uses to store and transmit her disjunctive memories also extend her trauma into our own corporeal and subjective experience. In turn, the ideo-aesthetics of Sadako's trauma subvert our own experiences and perceptions of both narrative progress and childhood growth, challenging the claustrophobic ideological binding of childhood to national progress and futurity in Japan at the millennial turn.

\section{The Ju-on Series}

While the temporal mechanics of the RING cycle may be complex, the JU-ON films extend RING's spiralling structure to disorienting extremes. JU-ON first appeared as two very popular television and direct-to-video movies in 2000, JU-ON: THE CURSE 1 and 2, before the theatrical release of JU-ON: THE GRUDGE 1 and 2 (Takashi Shimizu, 2002). The narratives of the theatrical releases follow on from these telemovies without a connective preamble for new viewers. In so doing, the theatrical releases render the brutal murder at the crux of the films as a particularly intangible traumatic event of the past, appearing only as brief and faded sepia intercuts that slice into the opening titles, without temporal or explanatory context. This terrible past event nevertheless shapes the trajectories of everything that occurs within each films' present diegeses.

The films centre on the spectres of a mother, Kayako, and her child, Toshio, who linger within the house in which they were brutally murdered by Kayako's husband and Toshio's father, Takeo. While the theatrical releases do not expose the reasons behind Takeo's murderous rage, the telemovies reveal that Takeo suspected his wife was having an affair with Toshio's classroom teacher. As is indicated by the intertitles that open almost all of the films - emphasizing the series' aesthetic of inescapable repetition - 'ju-on' denotes a curse that emerges when someone dies in the grip of a powerful rage, which gathers in the site of their death, in this case, the Saeki family's home. This curse involves the eternal repetition of the circumstances surrounding Toshio's and Kayako's deaths, enfolding any who come into contact with the house in a replaying of their trauma.

While in RING a videotape functions as the prosthetic vessel for the contagious spreading of the child's trauma, in JU-ON, people become prostheses for the curse's ever-extending grasp: those who have already been cursed tend to die in the grip of the powerful rage of Toshio and Kayako, creating new incarnations of the curse that extend beyond the bounds of 
the haunted house. The films thus depict a traumatic consequence of family breakdown and abuse, as the violent combustion of one family unit threatens to spread across the whole of Japanese society like a virus. The child, Toshio, is the embodied site of this traumatic collapse in contemporary societal structures and thus the primary vessel of the film's prosthetic trauma: Toshio drives most of the hauntings in the film, making contact with the viewer's sensorium by continually reliving his own trauma throughout the franchise. Diegetically, it is also Toshio who first draws the general public into the curse, as in the first film, ThE CURSE, his teacher visits the Saeki house because Toshio has not been attending school.

Anxiety surrounding the effects upon society of the ever-increasing incidence of school refusal (tôkôkyohi) was high in Japan at the time that the Ju-ON series was released: in a study of the phenomenon, Shoko Yoneyama points to data that demonstrates that school refusal increased dramatically throughout the 199os, and, by 1997, one in 53 lower middle school students were officially recognized as tôkôkyohi $(2000,79)$. What is more, Yoneyama includes in her study statements made by students who explain their school refusal as a mode of resistance against Japan's intense compulsory schooling system: 'students come to juxtapose their self-hood and school as fundamentally incompatible' (2000, 89) as 'student accounts indicate that even if the "triggers" of tôkôkyohi might be specific to each individual student, it is ultimately the entire school system that is at fault' (2000, 92), a rebellion which is 'gradually causing a legitimation crisis in Japanese schools and society' (2000, 92). Refracting anxieties about the tôkôkyohi phenomenon, Toshio's absence from school heralds his monstrous resistance to the child's sociocultural function, a resistance that, via his contagious supernatural curse, threatens Japanese society with total dissolution.

While brief flashes of Kayako's murder, and also Takeo's drowning of the family's black cat, are depicted throughout the Ju-ON films, Toshio's death is not shown: the child's trauma is circled around in all three films but never overtly represented, it is 'not experienced in time' (emphasis in original, Caruth, 1996, 62), in both senses of the phrase, enforcing a break in coherent temporality. Throughout the series, Toshio is known to be missing, but his murder has not been confirmed, for his body has never been located. In fact, the drowning of the cat functions as a signifier for Toshio's unrepresented death: Takeo is shown drowning the cat in the bathtub as it yowls and hisses, and at certain points throughout the films, Toshio is pictured around the bathtub as well, at one point with his head over the rim, submerged in the water. In his ghostly form, Toshio emits a cat's squeal, further reinforcing the way the cat's death comes to stand in for Toshio's own, unwitnessed 
trauma. Toshio's cat sounds metonymize the trauma inflicted upon him by his father, while indicating how the child draws his spectral force from this trauma to impose it back upon the adult society that failed him.

\section{Toshio as Prosthetic Trauma}

In a subversion of traditional haunted-house narratives in which the haunting is tied to a particular space, anyone who comes into contact with the house in which Toshio and Kayako died, however tangentially, experiences the wholesale disintegration of linear timeframes within their everyday lives: as soon as characters have encountered the ghosts, their narratives branch away from their previously linear route to become a disorientating corkscrew in which phone calls, conversations, and events repeat, replay, and overlap. Echoing the mechanics of prosthetic trauma and the internal alien, some characters start to (re)experience the circumstances surrounding Kayako and Toshio's murder psychically, as the traumatic past of the child and his mother is restaged in the present experience of other characters, even though it is not a past that 'belongs' to them. Toshio frequently clings and attaches himself to the bodies of the central characters or the furniture that they use - such as beds, chairs, and tables - aestheticizing his spectral function as prosthetic trauma.

Furthermore, Toshio embodies the subjective and temporal dislocations of the internal alien's prosthetic trauma: in both the original telemovie and first theatrical film, he appears as a mute and abused living boy in the central narrative thread, yet he simultaneously wreaks havoc as a ghost, with white skin and darkly lined eyes, in successive scenes that have hazy temporal connections to the overarching narrative. Thus, like Sadako, Toshio distorts the boundaries between the spectral and the material in a defiance of the ontological categorization that would permit his reinstatement into a coherent linear narrative. As a result, Toshio clearly refracts moral panics about the strange-changed child (kodomo ga hen $\mathrm{da}$ ) so prevalent around the millennial turn, as outlined in Chapter Five. He is both the victim of a corrosive and neglectful school and family structure - the extent of his suffering is realized too late by both his teacher and the viewer in The Curse, a belated recognition that is rendered as agonizing tension throughout the film - yet he is simultaneously a monstrous villain possessed by fits of murderous kireru. Toshio's dual appearance reflects the temporal split enforced by his death: the vacillation between his appearance as he was just before he died and alternatively as a pale ghost circulates the gulf of the traumatic event without recalling it directly or situating it on a chronological 
continuum. Toshio himself remains forever stuck at a particularly traumatic temporal moment and will never grow up to enact the future for which he is the receptacle, a temporal blocking that is registered as a deeply uncanny portent for the collapse in narrative progress that is to follow his initial appearance in each film.

For instance, in The Grudge, social worker Rika finds Toshio hiding in a cupboard early in the film, and, because she sees him in the form of a bruised and battered living child, she reports his presence to the police. Toshio disappears while she is making the phone call, but later, when being interviewed at the station, she recognizes the child in a police photograph. She is told that the boy has been missing for six years and would have grown up a great deal in that time, yet Rika shivers in terror because she saw him as he appeared in the photograph. This moment is a turning point in the film, in which Toshio becomes a figure to fear as well as to pity. From this juncture, Toshio's haunting forces characters and the audience of THE GRUDGE to experience his own dropping out of the linear processes of progress and growth, as his hauntings rearrange temporality as an inescapable loop in which characters are literally haunted by their own doomed futures. In THE GRUDGE 2, for instance, characters Tomoka and Noritaka hear a mysterious banging noise seemingly coming from the wall of their apartment, which occurs at exactly the same time each night. Eventually, as their experience of temporality becomes increasingly unstable, Tomoka and Noritaka (and the viewer) come to learn that this mysterious sound has been a reverberation from the future all along, emanating from Noritaka's own corpse: Kayako's ghost strangles him with her supernaturally charged hair, leaving him hanging from the apartment's ceiling. The banging is caused by Toshio, who playfully swings Noritaka's body backwards and forwards so that his feet periodically hit the wall. Thus, Tomoka and Noritaka have been locked into a temporal cycle from which there is no escape, although this does not become clear to them until moments before their death, evoking the traumatic affect of belated recognition in particularly tangled ways.

\section{Seriality, Asynchronous Narratives, and the Spectator's Prosthetic Trauma}

The spectator's experience of the Ju-ON films echoes the characters' belated recognition that they are trapped within a doomed temporal loop. The films are constituted of separate, episodic segments that layer different representations of the same time period from the perspectives of various characters as they meet their demise at the hands of Kayako and Toshio: as 
in RING, time in JU-ON thus functions as cacophonous heterogeneity rather than as a homogenous line. The individual segments do not come together to form a coherent tapestry of narrative meaning, instead serving to enclose the audience, like the characters, into a preordained circle. A sense of mastery over the events is denied in our attempts to follow a storyline to its resolution, as we instead experience how the characters' stories intersect and double back upon each other before inevitably leading to their death. This temporal plurality is enhanced on a larger scale by the numerous different versions of JU-ON in existence (including three American remakes), which do not progress in linear succession: each film presents a different group of people coming into contact with the haunted house. These characters are usually tenuously connected to those from previous films (their storylines set after or before those of the previous film), and the spectator is tasked with detecting this diaphanous connective tissue, following disorienting circuits back and forth through time in charting the ever-expanding web woven by the curse. This decentred heterogeneity thus induces a process of attentive recognition on the part of the spectator which underpins the horrifying affects of the films themselves: as Ndalianis explains, 'the pervasive intertextuality that's expressed through seriality [and] allusionism [...] requires the active engagement of the participant beyond the simple interaction with a story of character level' $(2012,10)$. While the films function as a series, consistently requiring viewers to draw forth their memories from previous films to make threads between the many different characters, when viewed chronologically, they do not gradually establish a linear master narrative, but render narrative time as increasingly plural and circuitous.

For instance, the final shot of THE CURSE 2 is a static exterior shot of the cursed house, overlaid with the chirpy voices of a group of teenage girls who have come to explore after hearing that the place is haunted. In the first theatrical release, THE GRUDGE, Toyoma, a detective involved in investigating Toshio's disappearance, arrives at the Saeki house intending to burn it down, an attempt to expel the curse once and for all. Yet, while he is in the house, he sees a group of teenage girls in one of the rooms, who are speaking the dialogue that constituted previous film THE CURSE 2's final scene. His vision of the girls is suffused with a sepia tone that usually signals that the past is replaying - and, for viewers who have seen the previous film, it is - but Toyoma is in fact seeing the diegetic future: he recognizes one of the girls as his daughter, Izumi, yet, according to this film's diegesis, Izumi is currently a young child, not a teenager. Toyoma and the teenage Izumi's eyes meet for a moment, before the room becomes shrouded in shadow once more and the girls disappear. Toyoma is then claimed by the curse before he is able to burn down 
the house. The film's next segment jumps forward to this flash from the future, to focus on the experience of the teenage Izumi soon after she has entered the cursed house. Izumi remains haunted by the death of her father when she was a young child, and her anxiety has heightened since she entered the haunted house in which he died with her friends and was confronted with a vision of him from the past: the incident that the viewer has just experienced from the perspective of Toyoma. Thus, for the viewer, a haunting from the past turns out to reverberate from the future, before being promptly flipped back into a haunting from the past, as chronological progression is folded back on itself.

The end of JU-ON 2 draws out the ideological implications of the series' frightening narrative and aesthetic contortion of linear time into doomed cycles. Overarching the film is the story of an actress, Kyoko, who has been haunted by Toshio throughout the film. Kyoko, who has been performing in a horror film set in the haunted house (her name's similarity to the ghostly Kayako is clearly no coincidence), has become pregnant. The film's climax depicts the terrible birth: instead of birthing a human baby, it is a miniature Kayako who crawls from Kyoko's body, and the monstrous creature kills everyone else in the delivery room. The final scenes depict Kyoko walking through the streets of Tokyo hand-in-hand with her monstrous progeny - a child born as a ghost. Recalling Sadako (and thus inciting the viewer's sense of dread via intertextual allusion), the reborn ghost of Kayako is a small creature in a white gown, with long black hair completely covering her face. The film ends with this child pushing Kyoko down the stairs of the bridge on which they have been walking, leaving her surrogate mother on the stairs to die as she totters off alone, into the busy Tokyo street. Thus, the series ends on a literal 'rebirth' of the curse, a claustrophobic vision in which children emerge into life as the vessels for the perpetuation of unresolved traumas of the past. The Ju-ON films ultimately aestheticize the catastrophic fracture that occurs when the child breaks apart from the linear path from education to work that defines childhood in Japan: the horizon of the future falls away for all who encounter Toshio and his vengeful mother, as traumatic 'time with the ghost' replaces each character's existence within a homogenous, ever-advancing national time.

\section{Conclusion}

At the liminal juncture represented by the turn of the millennium - a moment which also signified the continuation of one 'Lost Decade' into another - children became Japan's long-unacknowledged victims, and subsequently threatened to violently break out of their proper ideological 
place, symbolic contortions that threatened disturbing domino effects upon Japan's national identity. As Ryuji says of Sadako in RINGU, 'our fear has taken on a life of its own'. The J-horror films that emerged at the millennial turn can be seen as a response to the cultural trauma of the Lost Decade, in which long-standing narratives of rapid national progress were suddenly destabilized. The child is a powerful receptacle for such tensions, as this vessel for national futurity defies its overdetermined classification to instead monstrously foreclose the possibility of sociocultural advancement. The child's eruption through subjective and temporal boundaries makes contact with the viewer's sensorium on a deep level through the mechanism of prosthetic trauma, which constitutes both an affect and narrative preoccupation of these films. This prosthetic trauma aestheticizes the disturbing intensity yet challenging incoherence of traumatic memories - counter-memories resistant to homogeneous historical discourse - as in our interface with the films, we confront decaying, illegible images that circulate around traumatic pasts without coherently depicting them, in ways that become entangled with our own subjective processes of memory.

While this prosthetic trauma resonates beyond national boundaries (as is indicated by J-horror's vast transnational popularity in the early 21st century), the internal alien triggers particularly potent reverberations within a Japanese context, as every Japanese adult has been subject to the claustrophobic ideological entwinement of childhood development and national progress. Furthermore, Japanese adults of the period were (and are) implicated in the belated recognition of the extent to which children have been oppressed in the quest for national progress and productivity. Thus, the prosthetic traumas raised by the millennial internal alien have the potential to incite a retroactive reconsideration of their domestic audience's own experiences of growth, schooling, and childhood in Japan. In turn, these figures dramatize questions of culpability surrounding the current generation's own part in the continuation of confining models of education and child development in service of national ideology.

Parallel to this extra-diegetic potential, the temporal dislocations of the uncanny child interrupt both narrative progress and character development, inciting frightening moments of belated recognition in a simulation of traumatic experience. Furthermore, the subversive plurality of these characters also entails the resurfacing of earlier modes of childhood in Japan, in which the child was not locked into position as a sociocultural (and economic) unit within linear constructions of national development. The J-horror uncanny child thus resists the redomestication of the child within the unitary discourse of linear national progress, deconstructing the 
temporal mechanics that underlie this mode of consciousness. Although these characters' distortions of homogenous temporality are deeply uncanny, by challenging the overdetermined entwinement of a child's 'growing up' with national progress they expose the extent to which the Lost Decade represented an opportunity to reimagine the child's position in Japan's national narrative.

\section{Works Cited}

Balmain, Colette. 'Inside the Well of Loneliness: Towards a Definition of the Japanese Horror Film.' Electronic Journal of Contemporary Japanese Studies. 3 (May 2006): n.p. Web. 30 Sep. 2014.

-.Introduction to Japanese Horror Film. Edinburgh: Edinburgh University Press, 2008. Print.

Benson-Allott, Caetlin. Killer Tapes and Shattered Screens: Video Spectatorship from VHS to File Sharing. Berkeley: University of California Press, 2013. Print.

Bergson, Henri Louis. Matter and Memory. Trans. Nancy M. Paul and W. Scott Palmer. New York: Dover Philosophical Classics, 2004. Print.

Bowers, Faubion. Japanese Theatre. Rutland: Charles E. Tuttle Co., 1974. Print.

Caruth, Cathy. Unclaimed Experience: Trauma, Narrative, and History. Baltimore: The John Hopkins University Press, 1996. Print.

-.'Introduction: Trauma and Experience.' Trauma: Explorations in Memory. Ed. Cathy Caruth. Baltimore: The John Hopkins Univeristy Press, 1995. Print.

Deleuze, Gilles. Cinema 2: The Time Image. 1985. Trans. Hugh Tomlinson and Robert Galeta. Minneapolis: The University of Minnesota Press, 1997a. Print.

Dona, Giorgia. 'Collective suffering and Cyber-memorialisation in Post-genocide Rwanda.' Trauma, Media, Art:New Perspectives. Ed. Mick Broderick and Antonio Traverso. Cambridge: Cambridge Scholars Press, 1999. Print.

Edelman, Lee. No Future: Queer Theory and the Death Drive. Durham: Duke University Press, 2004. Print.

Foucault, Michel. Language, Counter-Memory, Practice. Ed. Donald F. Bouchard. New York: Cornell University Press, 1977. Print.

—.'Society Must Be Defended': Lectures at the Collège de France 1975-1976. Trans. David Macey. New York: Picador. 2003. Print.

Hand, Richard J. 'Aesthetics of Cruelty: Traditional Japanese Theatre and the Horror Film.' Japanese Horror Cinema. Ed. Jay McRoy. Edinburgh: Edinburgh University Press, 2006. 18-29. Print.

Haque, D. 'Horrific Reproductions: Pathology and Gender in Koji Suzuki's Ring Trilogy.' The Scary Screen: Media Anxiety in The Ring. Ed. Kristen Lacefield. Surrey: Ashgate Publishing Ltd., 2010. 191-205. Print. 
Kafu, Nagai. 'The Fox.' 1909. Autumn Wind and Other Stories. Ed. and Trans. Lane Dunlop. North Clarendon: Charles E. Tuttle Publishing Company, 1994.11-30. Print. Landsberg, Alison. Prosthetic Memory: The Transformation of American Remembrance in the Age of Mass Culture. New York: Columbia University Press, 2004. Print.

Lim, Bliss Cua. Translating Time: Cinema, the Fantastic and Temporal Critique. Durham: Duke University Press, 2009. Print.

Lowenstein, Adam. 'Ghosts in a Superflat Global Village: Globalization, Surrealism and Contemporary Japanese Horror Films.' Post-Script. 28.2 (2009): 59-72. EBSCO Host Humanities International Complete. Web. 30 Sep. 2014.

—.'Globalized Spectatorship: Ring Around the Superflat Global Village: J-Horror Between Japan and America.' Dreaming of Cinema: Spectatorship, Surrealism and the Age of Digital Media. New York: Columbia University Press, 2015· 79-116. Print.

Lury, Karen. The Child in Film. London: I.B. Tauris \& Co. Ltd., 2010. Print.

Marks, Laura U. The Skin of the Film: Intercultural Cinema, Embodiment and the Senses. Durhman: Duke University Press, 2000. Print.

McRoy, Jay. Nightmare Japan. Amsterdam: Rodopi, 2008. Print.

Medina, José. 'Toward a Foucaultian Epistemology of Resistance: Counter-Memory, Epistemic Friction, and Guerrilla Pluralism.' Foucault Studies 12 (2011): 8-35. EBSCO Host Humanities International Complete. Web. 30 Sep. 2014.

Miyao, Daisuke. The Aesthetics of Shadow: Lighting and Japanese Cinema. Durham: Duke University Press, 2013. Print.

Nakata, Hideo. Interview by Donald Totaro. 'The "Ring” Master: Interview with Hideo Nakata.' OffScreen.com, Canada Council for the Arts. July 200o. Web. 30 Sep. 2014.

Ndalianis, Angela. The Horror Sensorium: Media and the Senses. Jefferson: McFarland, 2012. Print.

Phu, Thy. 'Horrifying adaptations: RINGU, THE RING, and the cultural contexts of copying.' Journal of Adaptation in Film and Performance. 3.1 (2010): 43-58. Print.

Richards, Andy. Asian Horror. Herts: Kamera Books, 2010. Print.

Robertson, Jennifer. 'Furusato Japan: The Culture and Politics of Nostalgia.' International Journal of Politics, Culture and Society. 1.4 (1988): 494-518.JSTOR Arts and Sciences VI. Web. 30 Sep. 2014.

Sanders, Vicky. 'Dancing and the Dark Soul of Japan: An Aesthetic Analysis of Butoh.' Asian Theatre Journal 5.2 (1988): 148-163. JSTOR Arts and Sciences III. Web. 30 Sep. 2014.

Sōseki, Natsume. Ten Nights' Dreams. 1908. Trans. Takumi Kashima and Loretta R. Lorenz. London: Soseki Museum in London, 2000. Print.

Stein, Bonnie Sue. 'Butoh: Twenty Years Ago We Were Crazy, Dirty, and Mad.' Moving History/Dancing Cultures. Ed. Ann Dils and Ann Cooper Albright. Middletown: Wesleyan University Press, 2001. 376-383. Print. 
Suzuki, Koji. Ring. Trans. Robert B. Rohmer and Glynne Walley. New York: Vertical, 2004. Print.

Tateishi, Ramie. 'The Japanese Horror Film Series: Ring and Eko Eko Azarak.' Fear Without Frontiers: Horror Cinema Across the Globe. Ed. Steven Jay Schneider. Godalming: FAB Press, 2003. Print.

Wada-Marciano, Mitsuyo. 'J-Horror: New Media's Impact on Contemporary Japanese Horror Cinema.' Horror To the Extreme: Changing Boundaries in Asian Cinema. Ed.Jinhee Choi and Mitsuyo Wada-Marciano. Hong Kong: Hong Kong University Press, 2009. 15-39. Print.

Webber, Andrew Lloyd. The Phantom of the Opera. Lyrics by Charles Hart and Richard Stilgoe. Milwaukee: Hal Leonard, 1987.

Wee, Valerie.Japanese Horror Films and their American Remakes. London: Routledge, 2013. Print.

-.'Patriarchy and the Horror of the Monstrous Feminine: A Comparative Study of Ringu and The Ring.' Feminist Media Studies 11.02 (2011a): 151-165. Taylor and Francis Journals Complete. Web. 30 Sep. 2014.

-.'Visual Aesthetics and Ways of Seeing: Comparing Ringu and The Ring.' Cinema Journal 50.2 (2011b): 41-6o. JSTOR Arts and Sciences III. Web. 30 Sep. 2014.

Wetmore, Kevin J. 'Technoghosts and culture shocks: sociocultural shifts in American remakes of J-horror.' Post-script 28.2 (2009): 72-83. EBSCO Host Literary Reference Centre. Web. 30 Sep. 2014.

White, Eric. 'Case Study: Nakata Hideo's Ringu and Ringu 2.' Japanese Horror Cinema. Ed. Jay McRoy. Edinburgh: Edinburgh University Press, 2006. 38-51. Print.

Yoneyama, Shoko. 'Student Discourse on Tôkôyohi (School Phobia/Refusal) in Japan: Burnout or Empowerment.' British Journal of Sociology of Education 21.1 (2000): 77-94.JStOR Arts and Sciences IV. Web. 30 Jan. 2015.

\section{Filmography}

Dark Water [Honogurai mizu no soko Kara]. Dir. Hideo Nakata. 2002. Section 23 Films, 2005. DVD.

Eyes Without a Face [Les Yeux Sans Visage]. Dir. Georges Franju. Champs-Elysées Productions, 1960. Film.

Ju-ON: The Curse [Ju-ON]. Dir. Takashi Shimizu. 2000. Lionsgate Home Entertainment, 2003. DVD.

Ju-ON: The CuRSE 2 [Ju-ON 2]. Dir. Takashi Shimizu. 2000. Lionsgate Home Entertainment, 2003. DVD.

Ju-ON: The Grudge [Ju-ON]. Dir. Takashi Shimizu. 2002. Lionsgate Home Entertainment, 2005. DVD. 
Ju-On: The Grudge 2 [Ju-ON 2]. Dir. Takashi Shimizu. 2002. Lionsgate Home Entertainment, 2006. DVD.

The Locker [Shibuya KaIdAn]. Dir. Kei Horie. Bad Taste Visual Voice and Geneon Entertainment, 2004. Film.

One Missed Call [Chakushin ARI]. Dir. Takashi Miike. 2003. Tokyo Shock, 2006. DVD.

Reincarnation [RInNe]. Dir. Takashi Shimizu. 2005. Lionsgate Home Entertainment, 2007. DVD.

Ringu. Dir. Hideo Nakata. 1998. DreamWorks Video, 2000. DVD.

Ringu o: Birthday [Ringu o: Basudei]. Dir. Norio Tsuruta. 2000. Paramount Catalogue, 2013. DVD.

RINGU 2. Dir. Hideo Nakata. 1999. DreamWorks Video, 2005. DVD. 